\title{
Philosophical Mindfulness An Essay about the Art of Philosophizing
}

\author{
MINDFULNES FILOSÓFICO \\ UN ENSAYO SOBRE EL ARTE DE FILOSOFAR \\ MiCHAEL NOAH WeISS \\ Norwegian Society for Philosophical Practice \\ michaelnoahweiss@gmail.com
}

RECIBIDO: 17 DE JULIO DE 2016

ACEPTADO: 14 DE NOVIEMBRE DE 2016

\begin{abstract}
What skills or qualities with a philosophical practitioner are required in order to perform and facilitate good philosophical dialogues? Is good dialogue facilitation only a question of respective techniques or is the ethical attitude of the philosophical practitioner also of significant relevance? These questions are further investigated in this essay, and - as some sort of result - pointed out that the development of so-called phronesis (practical wisdom or mindfulness) with the philosophical practitioner plays a decisive role when he or she is facilitating dialogues and is a key feature in the art of philosophizing.
\end{abstract}

Keywords: Philosophical practice, phronesis, mindfulness, dialogue facilitation

Resumen: ¿Qué habilidades o cualiddes, además de las inherentes a la práctica filsófica son necsarias para llevar a cabo y facilitar buenos diálogos filosóficos? ¿Consiste la facilitación de un diálogo exclusivamente en un asunto de técnicas o se requiere una actitud ética también significativa? Estas cuestiones serán minuciosamente investigadas en este trabajo y, como una suerte de resultado, se señalará que el desarrollo de la, así denominada, phronesis (sabiduría práctica o visión plena (mindfulnes)) juega un rol decisivo en el orientador filosófico cuando facilita diálogos y, asimismo, constituye una característica clave en el arte de filosofar.

Palabras clave: Filosofía Aplicada, phronesis, mindfulness, facilitación de diálogos. 


\section{On the guiding question of this essay}

Quite early after it came into existence, the field of philosophical practice was marked by a great variety of approaches and concepts ${ }^{1}$. And with this diversity in terms of approaches, concepts and practices, an intense discussion about the essence of this new discipline came along ${ }^{2}$. Up until today, this discussion never came to a final answer or common conclusion. And maybe this is not even necessary, since different points of view allow for the discovery of new potentials and developments within the field.

However, what all philosophical practices seem to have in common - and this is one of the basic assumption of this essay - is that they strive to offer ways to create, facilitate and perform dialogues $^{3}$. What methodological structures, formats or even purposes these dialogue practices have, is of course another question. But a philosophical practice that manages without the performance of a dialogue (and one can also have a dialogue with oneself ${ }^{4}$ ) would be the 'black swan' among the philosophical practices currently available, so to say. Therefore, it appears that there is one feature in particular that all philosophical practitioners tacitly share (no matter, whether they work at schools, with counseling, in hospitals, prisons, at universities etc.): They all want to facilitate and perform good (philosophical) dialogues. And it is this aspect that this essay is dealing with - the performance of good

1 see LAHAV, Ran \& DA VENZA TILLMANNS, Maria (eds.): Essays on Philosophical Counseling, Plymbridge Distributors Ltd., Gloucester, 1995.

2 RAABE, Peter: Philosophical Counseling. Theory and Practice, Praeger Publishers, Santa Barbara, CA, 2001, p. 120f.

${ }^{3}$ see WEISS, Michael Noah (ed.): The Socratic Handbook. Dialogue Methods for Philosophical Practice, LIT Publishing, Vienna, 2015.

${ }^{4}$ see AMIR, Lydia: "The Tragic Sense of the Good Life" or NIEHAUS, Michael: "Philosophy as a Way of Life. Exercises in Self-Care", in WEISS, Michael Noah (ed.): The Socratic Handbook. Dialogue Methods for Philosophical Practice, LIT Publishing, Vienna, 2015. 
philosophical dialogues. However, the intention behind this essay is not to evaluate and critically reflect the different methods and formats within philosophical practice, since as a format or method they all have 'a right to exist'. Rather, the guiding question of investigation focuses more on the philosophical practitioner, who performs and facilitates dialogues and it reads:

- What skills or qualities with the philosophical practitioner are required in order to perform and facilitate a good dialogue?

In a certain respect, this question is a normative one. But before going into it, a closer look at the term 'good dialogue' is necessary.

\section{The good life - an analogy}

It is of course - at least to a certain extent - a sheer presupposition that all philosophical practitioners want to perform good dialogues. On the other hand, however, intending to perform a 'weak' or 'poor' dialogue would simply make no sense. But even if one agrees that intending to perform poor or weak dialogues makes no sense, the question remains, what then is a good dialogue? Here an analogy to the Nichomachean Ethics of Aristotle seems to be useful in which he argues that the highest goal in life - shared by all human beings - is to live a good life ${ }^{5}$. However, even if we assume that Aristotle is right, the idea of what the good life is would differ from individual to individual. This seems to be similar with philosophical practitioners and their supposedly intention to perform good dialogues. However, even if we cannot give a common answer to what a good (philosophical) dialogue is, it can be a kind of guideline or normative idea, just like the good life is.

${ }^{5}$ see ARISTOTLE: Nichomachean Ethics, 1097a. 


\section{The metaphor of the guitar players}

In order to further outline the direction in which I intend to go in this essay, I would like to use a metaphor - the metaphor of the guitar players: Obviously, there are guitar players, and there are great guitar players. There are those "Smoke on the Water" players, who just began practicing, and then there are those who virtuously master their instruments (and there are of course also many in between). Then there are those who are well trained as well as those not so well trained, but who somehow inspire the listener with their playing. Then there are guitar players who play by notes, and others who improvise. In fact, there are incredibly many different ways of playing a guitar, both in terms of style and quality. And here the question comes up, how to improve one's style and quality in order to become a great guitar player? Regular practice and years of experience seem to be important in this respect - but even if you are an experienced guitar player who practices frequently, then this is still no guarantee that your playing will become outstanding in style and quality. Maybe you too have once heard guitar players who possessed extraordinary playing techniques and skills to master their instrument while something was 'still missing' in order to call their playing inspiring everything was 'done right', but still their playing did not sound very inspired. In other words, great guitar playing is not only a question of skills. There is more to it than the mastery of playing techniques that make music sound great.

\footnotetext{
6 "Smoke on the Water" is a song by the band Deep Purple. Its hook line is both an attracting Rock ' $n$ Roll tune as well as simple to play. Probably millions of youngsters began their guitar playing with this song.
} 


\section{Reframing the metaphor of the guitar players}

One could now ask what kind of qualities a guitar player needs in addition to experience and skills in order to become a great guitar player. For the moment, I would like to leave this question unanswered. Rather, I would like to reframe this metaphor of the guitar players into the context of dialoguing.

\section{Techné}

For Aristotle the ability to play the lyre (a kind of Ancient guitar) fell within the realm of so-called techné $e^{7}$. Techné can be translated with technical knowledge or craftsmanship and even art. At first sight, it might not appear logical why Aristotle associates art with technical knowledge. But what he means is that art is both the knowledge and the skills to put an idea into reality, i.e. to proceed from an image that a painter has in his or her mind to the finished painting. The decisive point here is that already in the beginning of the 'production process' there is an idea of what the product in the end should 'look like' - and that idea is guiding the whole development process. In this sense Aristotle differed techné from episteme (theoretical knowledge) and phronesis (practical wisdom or moral knowledge) - on the latter we will have a closer look later. In a sense, techné represents not only know-how but also the capability to properly apply this know-how. In other words, technè is not only concerned with the knowledge of how to do or produce something (i.e. a vase or a house) but also with the acquisition of the skills and techniques necessary for doing that. The question now is, again, whether playing music or making art, is only a question of techné - or, to come back to the topic of dialoguing,

${ }^{7}$ see ARISTOTLE: Magna Moralia, 1197a 33. 
whether facilitating and performing a dialogue is simply a question of craftsmanship in the sense of techné.

\section{Dialogues are unpredictable}

The short answer to the last question is 'no': It needs more than a skilled dialogue-facilitator - in our case, a philosophical practitioner - in order to have a good dialogue. If a good dialogue would solely depend on skills, techniques and methods and their proper application then it would not only be 'predictable' what a philosophical practitioner has to do in order to 'produce' a good dialogue, but also the result and outcome of a dialogue would be, at least in certain respects, predictable. However, isn't it one of the key-features of a philosophical dialogue that its outcome is not predictable, and furthermore, that most (if not all) dialogue methods in philosophical practice rely to a great extent on improvisation, simply because they are dialogical ${ }^{8}$ ?

\section{A good dialogue is like a good jazz performance}

A good dialogue might be comparable with a good jazz performance: The key-feature of such a performance lies in the spontaneous interaction - the improvisation - between the musicians. And though jazz musicians in general have brilliant playing skills, the skillful capability of playing an instrument cannot account alone for good improvisation. And this appears to

\footnotetext{
${ }^{8}$ LINDSETH, Anders: "Being Ill as an Inevitable Life Topic. Possibilities of Philosophical

Practice in Health Care and Psychotherapy“", in WEISS, Michael Noah (ed.): The Socratic Handbook. Dialogue Methods for Philosophical Practice, LIT Publishing, Vienna, 2015.
} 
be the same in a dialogue, which also can be understood as a spontaneous form of interaction between the dialogue participants: A philosophical practitioner might have extraordinary knowledge in philosophy as well as expertise and knowledge of different dialogue methods, but this gives little predictive value as to whether the dialogue that he or she is facilitating will be inspiring and giving.

\section{The Art of Improvisation}

One of the reasons why knowledge in philosophy, as well as expertise in dialogue practices, cannot account alone for a giving and inspiring dialogue is because the 'art' of improvisation cannot be taught. If it would be, then it would not be improvisation. Improvisation - at least to a certain degree - can be understood as the way in which one deals with unexpected situations. There are certainly situations that we are unexpectedly confronted with, which simply make us scared - and then we would go into 'fight-, flight- or freeze'-mode. The 'art' of improvisation on the other hand would mean that we would try to 'make the best out of the situation'. This already indicates that there are two principal attitudes towards unexpected situations: On the one side of the spectrum we find the more 'negative' attitude, meaning that one is trying to 'get out of this situation'. On the other side there is the more 'positive' attitude, meaning that one is trying to embrace and value the unexpected situation by seeing its chances and potentials by trying to deal with it more actively. To call this 'positive', improvising attitude an 'art' seems to be far fetched, however. First, because it seems to have little to do with Aristotle's techné, in the sense of craftsmanship and art - especially if we understand art in the previously suggested way where already in the beginning of the 'production' there is an idea of the 'product' that guides the 
whole process. On the contrary, the absence of such an idea of the 'end product' seems to be an inherent aspect of the nature of improvisation. Secondly, because it seems to be sheer nonsense to call improvisation an art form, like visual arts, decorative arts, digital arts, performing arts etc. However, if one takes a closer look at the etymological roots of the term 'art', then one will find that it traces back to the Sanskrit word rtih, which is translated with 'manner' or 'mode'. In German, for example, the term Art still means 'manner' and 'mode'. And also the Old English expression of thou art ('you are') ${ }^{10}$ relates to a mode of being. With this in mind it seems to be legitimate to speak of the art of improvisation in the sense of a mode of improvisation. And now we are eventually getting a better understanding of what jazz musicians are doing in a jazz performance: They are getting into a 'mode' - a 'mode of improvisation'.

\section{The Art of Philosophizing}

With the translation of the term 'art' in the sense of a mode, we can now continue and see whether we can use this concept of art also in the context of philosophical dialogues. The activity primarily done in a philosophical dialogue is the activity of philosophizing. And now we can ask, what do we actually understand by the term 'philosophizing'? This seems to be a delicate question. Some might say that philosophizing is a (reflective) activity in which one goes from the concrete to the more general and abstract (a movement in the thinking process that one can find in the Socratic method after

\footnotetext{
9 ONLINE ETYMOLOGY DICTIONARY: "art" available in HUhttp://www.etymonline.com/index.php?term=artUH (last access July $11^{\text {th }}$ 2016)

${ }^{10}$ DICT.CC: "thou art" available in HUhttps://www.dict.cc/?s=thou+artUH (last access July $11^{\text {th }}$ 2016)
} 
Leonard Nelson, for example ${ }^{11}$ ). Others would say that philosophizing means to investigate general aspects of the human condition, like freedom, responsibility, meaning etc. ${ }^{12}$ For the purpose of this essay however, I suggest a more literal understanding of the term 'philosophizing'.

\section{Philo-sophia}

Philosophy in its literal translation means the love of wisdom (philo-sophia). A philosopher is a friend of wisdom. And to philosophize would then simply mean to love or to be fond of wisdom (as an aside it can be noted that all these three terms philosophy, philosopher, philosophizing - suggest a positive emotional disposition towards wisdom, rather than its ownership or acquisition). However, what wisdom (sophia) is and what it is not, is again, a challenging question. Intuition tells us what it is not: knowledge - if wisdom would simply be mere knowledge then it can be acquired and 'owned' (and then philosophers would be called sophists), but it does not seem to be that easy with wisdom. And also, a person who has great knowledge of something is not necessarily a wise person. Further help can be found with Aristotle who offers some valuable categorization. He differed between theoretical wisdom (sophia) ${ }^{13}$ and practical wisdom (phronesis) ${ }^{14}$. While theoretical wisdom - in short and simple terms - is rather concerned with the understanding of the $\operatorname{cosmos}^{15}$, practical

${ }^{11}$ see WEISS, Michael N. (ed.): The Socratic Handbook. Dialogue Methods for Philosophical Practice, LIT Publishing, Vienna, 2015.

${ }^{12}$ TEICHMANN, Jenny \& EVANS, Kathrine C., Philosophy - A Beginner's Guide, Blackwell, Oxford, 1999, p. 1.

${ }^{13}$ see ARISTOTLE: Nichomachean Ethics, 1141.

${ }^{14}$ see ibidem, 1140.

${ }^{15}$ see ibidem, 1141. 
wisdom is concerned with a proper, that is, virtuous understanding of a given situation qua action ${ }^{16}$. In other words, sophia is a wisdom related to the general, while phronesis is a wisdom related to the concrete situation, but both forms of wisdom are about understanding (which is not necessarily the same as knowing).

\section{Sophia vs. phronesis}

An assumption that I would like to introduce now is that philosophizing - and with that the facilitation of philosophical dialogues - can but does not have to be about sophia, that is, theoretical wisdom (i.e. a dialogue can be about virtuousness, which rather can be attributed to phronesis than to sophia). However, philosophizing is always - at least in a certain respect about phronesis, that is, practical wisdom. What is meant by that? A philosophical dialogue can but does not have to be about certain aspects of the cosmos, about certain aspects of the human being in the world - this is not a necessity. A philosophical dialogue can also be about practical wisdom, that is, about questions concerned with what one ought to do in a given situation. However - and this is my central point - a philosophical dialogue is, or let us better say should always be, concerned with phronesis. With that I do not intend to say that the topic of a dialogue always has to be about certain aspects of practical wisdom, but that in a dialogue, practical wisdom should always be an issue qua action - otherwise a dialogue as such cannot take place. It is the ethical dimension put into practice between and among the dialogue partners that is addressed here. But in order to explain what is meant with phronesis being an essential dimension in a dialogue, we first have to look at what a dialogue actually is.

${ }^{16}$ see ibidem, 1140. 


\section{The Community of Inquiry}

If a philosophical dialogue - in a metaphorical sense - is understood like some kind of 'canvas' for the activity of philosophizing, then we have to ask, what this 'canvas' has to be like in order to 'hold and depict the colors' put onto it in the creative process of philosophizing. The question here is, what are the inherent ethical 'frameworks' of a dialogue in order to hold the 'canvas' steady on which the (art of) philosophizing takes place? And here of course one can also ask, what is a dialogue? In short terms - and with respect to Matthew Lipman's Community of Inquiry concept ${ }^{17}-\mathrm{a}$ dialogue is a format of communication in which a topic, a question, a phenomenon etc. is investigated together with others (in a group) ${ }^{18}$. The emphasis here is on 'together' (and in a sense, I can also have a dialogue together with myself). In this respect, an often-used metaphor to explain what a dialogue is, is the one of the Elephant and the Blind Scientists ${ }^{19}$ : A group of blind scientists who never saw an elephant before (because how could they, since they are blind) are brought to an elephant. Each scientist is then touching a different part of the elephant. When asked what an elephant is, the one who is holding the trunk would say 'An elephant is like a snake', the one who is embracing a leg would say 'An elephant is like a tree', the one who is touching the ear of the elephant would say 'An elephant is like a fan', and so on. If we would ask now 'Which one of the scientists is

${ }^{17}$ see LIPMAN, Matthew: Thinking in Education, Cambridge University Press, Cambridge, 2003, p. 84.

${ }^{18}$ see WEISS, Michael Noah: "Ethical Guidelines for Philosophical Dialoguing? From Global Ethic Towards a Professional Ethics for Philosophical Practice", in Journal of the American Philosophical Practice Association, Nr. 3, Vol. 10, 2015.

${ }^{19}$ see SHIELDS, Patricia M.: "The Community of Inquiry: Classical Pragmatism and Public Administration", in Administration \& Society, Nr. 5, Vol. 35, 2003, p. 513. 
right?' then we would simply pose the wrong question. In fact, all of the scientists are partly right and a deeper understanding of an elephant is can only be approached when putting all of these different views together. When reframing this metaphor of the Elephant and the Blind Scientists into the context of dialoguing, then one of the main characteristics of a dialogue is that different views are not only allowed but also actually necessary in order to get a deeper understanding of the topic or the phenomenon under investigation. In this respect a dialogue is different from a discussion or a debate, where it often is about finding the best argument or winning the debate. A dialogue is not a competition you win. If one dialogue participant starts to try to 'win' the dialogue or to find the best argument and the others join this 'competition', then they would still communicate with each other, but the dialogue and the joint exploration as such would have ceased to exist. A dialogue is rather a form of investigative cooperation. And with the emphasis on the term 'cooperation' it is a fundamentally ethical or a phronetic enterprise - and it is in this sense, why a dialogue is or should always be concerned with phronesis. In this respect, Kenneth Seeskin can be mentioned, who, in his book "Dialogue and Discovery", states "If nothing else, dialogue requires cooperation with another person, which, in turn, requires appropriate forms of behavior. This entire way of looking at knowledge comes to a head in the Socratic dictum that virtue is knowledge." ${ }^{20}$ With what Seeskin calls the 'Socratic dictum' here, he is referring to a passage in Plato's dialogue Meno, in which Meno and Socrates investigate the nature of virtue ${ }^{21}$. Interestingly, certain authors like Shaun Gallagher have suggested that in this passage the term 'virtue' can be translated with phronesis and

\footnotetext{
20 SEESKIN, Kenneth: Dialogue and Discovery. A Study in Socratic Method, State University of New York Press, New York, 1987, p. 3f.

${ }^{21}$ see PLATO: Meno, $96 \mathrm{~d}$.
} 
'knowledge' in terms of self-knowledge ${ }^{22}$. With this in mind, let us further examine the attitude of Socrates, which he adopted in his dialogues.

\section{The phronetic attitude of Socrates}

When taking a closer look at the Socratic dialogues of Plato, then one most likely comes to the conclusion that it is the figure of Socrates himself, who establishes the framework for the authentic philosophizing in these dialogues. To be more precise, it is Socrates' attitude towards the dialogue as such, and of course towards his dialogue partner, which seems to be decisive for the progress and the course of the respective dialogue. And this attitude of Socrates - surely presented in an idealized way by Plato - can be understood to be ethical and virtuous in its essence. With this however, I do not intend to say that Socrates was acting according to certain moral norms, rules or principles. Rather, he showed a true concern for the topic of the dialogue, as well as for his interlocutors $^{23}$. In this way, one could say that Socrates was concerned with the given situation in which the dialogue happened. To take it a step further, one could even claim that Socrates was acting phronetically both in the situation of the dialogue as well as towards his dialogue partners (and towards himself), or, to put it into the words of Seeskin: "The dialogues present him [Socrates] as a man with deep moral convictions" 24 . However, when referring the attitude of Socrates, which he adopted in his dialogues, to the term phronesis, then it has to be explained what is meant by it here. Phronesis (practical wisdom), as previously mentioned, is about

${ }^{22}$ see GALLAGHER, Shaun: Hermeneutics and Education, Suny Press, Albany, NY, 1992, p. 198f.

${ }^{23}$ see SEESKIN, Kenneth: Dialogue and Discovery. A Study in Socratic Method, State University of New York Press, New York, 1987, p. 3.

${ }^{24}$ ibidem, p. 8. 
doing good and acting virtuously in the given situation, with regards to the aim of living a good life overall ${ }^{25}$. If phronesis is understood in this way, then Socrates seems to have possessed this kind of wisdom, or let us better say this practically wise attitude. Examining life with regards to live a good and virtuous life overall was the reason why he engaged in these dialogues in the first place $^{26}$. In these dialogues, Socrates stayed true to himself, but he was also open-minded, he had an authentic interest in the topic under investigation, and he never made anyone look like a fool just for the fun of it - it was not really Socrates, but the course of the dialogue, which made others look like fools because they were obviously not as wise as they thought they would be. And that can also be read as a sign that they were not as phronetic as Socrates, when being 'trapped' in aporia - because if they would have been, they would have had admitted that they would know that they knew nothing, just like Socrates. And here humbleness, as an ethical dimension of the Socratic wisdom of ignorance, comes to the fore. But humbleness alone does not make phronesis. When one takes a look at how phronesis is translated in the respective philosophical literature, then we find terms like prudence or moral knowledge ${ }^{27}$, for example. However, prudence can easily be misunderstood in terms of cautiousness and moral knowledge can easily be mixed up with some kind of knowledge about morals. Therefore, both translations do not really seem to fit when talking about the phronetic attitude of Socrates - he was neither cautious nor did he claim any knowledge about morals. A more proper translation, as it seems, is offered by McEvilley: In his extensive work on Ancient

${ }^{25}$ see PLATO: Meno, $88 \mathrm{c}$.

${ }^{26}$ see PLATO: Apology, 38a.

${ }^{27}$ GALLAGHER, Shaun: Hermeneutics and Education, Suny Press, Albany, NY, 1992, p. 197. 
Greek philosophy titled with "The Shape of Ancient Thought", he translates phronesis with the term mindfulness ${ }^{28}$.

\section{Phronesis as mindfulness}

At first sight one might be a bit confused with the translation of phronesis as mindfulness, since mindfulness rather reminds of the same-named and currently popular training-approach for personal growth, which is rooted in certain Buddhist practices ${ }^{29}$. However, if one agrees with Dorothy Tarrant when stating that "The essence of dialogue lies in the interaction of human minds" ${ }^{30}$, then mindfulness does not appear to be entirely out of place with regards to dialoguing. Furthermore, when one looks closer then Socrates seems to have been mindful in the true sense of the word. Not only because he was 'full of minds', but he also 'fully minded' his dialogues, as well as his interlocutors. And here two fundamental dimensions of mindfulness are revealed: First, a reflective dimension and second, a caring dimension. To be mindful of something (i.e. of what others say and express in a dialogue as well as of my own thoughts, ideas and intuitions) means on the one hand to take it into consideration, - and this would relate to the reflective dimension of mindfulness. On the other hand, to be mindful can also be understood in the sense of taking care of something or somebody - which would relate to the caring dimension of mindfulness (i.e. mindful listening in a dialogue can be understood as caring for what is said and expressed by others, which might not

${ }^{28}$ see McEVILLEY, Thomas: The Shape of Ancient Thought, Allworth Press, New York, NY, 2002, p. 609.

${ }^{29}$ see HARRINGTON A. \& DUNNE, J. D.: "When mindfulness is therapy: Ethical qualms, historical perspectives", in American Psychologist, Nr. 7, Vol. 70, 2015.

${ }^{30}$ TARRANT, Dorothy: "Style and Thought in Plato Dialogues", in Classical Quarterly, Nr. 42, 1948, p. 28. 
simply be thoughts, but also feelings, beliefs, life stances, hopes and fears etc.). In short, the caring dimension of mindfulness means to care about others and their concerns, to take them seriously, and to respond to them in a respons-ible way ${ }^{31}$. One can find this caring dimension with Socrates in a dialogue with Protagoras, for example:

Protagoras: I don't think it is quite so simple, Socrates, so that I should grant that justice is holy and holiness just. It seems to me there is a distinction here. But what difference does it make? If you wish, let us agree that justice is holy and holiness just.

Socrates: Oh, no! I don't want t examine this 'If you like' or 'If you think' but to examine you and me. When I say 'you and me' I mean that one can best examine the issue by taking away the 'ifs'. ${ }^{32}$

With this passage it is pointed out that Socrates was not interested in 'logical games' or in hypothetical 'ifs'. On the contrary, he was interested and concerned with the topic under investigation as well as with the person he is investigating this topic with. In this way, mindfulness appears to have little to do with mere theorizing, rather it seems to be a certain kind of awareness - a fundamental attitude towards the given situation and towards the people who are involved. With reference to this passage in the dialogue Protagoras, Seeskin states that

"What is at stake in a Socratic dialogue is not, at least not primarily, the logical relations between propositions but the interaction of moral agents. That is what Socrates means when he refuses to allow Protagoras to use hypotheticals and claims that what he really wants to examine are 'you and me'., 33

31 see FRANKL, Viktor E.: Man's search for ultimate meaning, Perseus Publishing, Cambridge, MA, 2000, p. 29.

32 see PLATO: Protagoras, 331c.

${ }^{33}$ SEESKIN, Kenneth: Dialogue and Discovery. A Study in Socratic Method, State University of New York Press, New York, 1987, p. 3. 
At this point, one might interpose that phronesis is not only about an attitude towards or an awareness of the given situation in the sense of knowing how to act good and virtuously in that respective situation. Phronesis as introduced in the Socratic dialogues of Plato $^{34}$ or in the Nichomachean Ethics of Aristotle ${ }^{35}$ is also concerned with living a good and virtuous life overall. How is this eudaimonic characteristic of phronesis 'echoed' in the term mindfulness? The answer seems to be rather simple and it was already outlined in the remarks about the phronetic attitude of Socrates: The fundamental reason why the figure of Socrates can be called mindful (in the sense as described here) is because he truly cared about life and how to live it. Until the end of his life he was driven to figure that out, which is also reflected in his famous proverb "The unexamined life is not worth living"36. In other words, his concern to live a good and virtuous live overall - that is, to pursue eudaimonia in a 'sustainable' way, as it were - was the reason why he employed (or better, could employ) a mindful attitude in the first place. Therefore, in terms of phronesis the philosophical mindfulness as presented here, can be seen as being intimately linked with an eudaimonic perspective or dimension - it represents the motivational framework for being mindful in the concrete and given situation. With that, it seems to be this eudaimonic perspective, which is the 'trigger' when having or facilitating a philosophical dialogue, for example. Without that perspective a true and authentic concern for the topic and its investigation may vaporize in the long run.

\footnotetext{
${ }^{34}$ see PLATO: Meno $87 \mathrm{~d}-89 \mathrm{a}$.

35 see ARISTOTLE: Nichomachean Ethics, 1097a.

${ }^{36}$ PLATO: Apology, 38a.
} 


\section{The art of philosophizing as a phronetic mode of being}

With these remarks on the phronetic attitude of Socrates, one can conclude that: If one speaks of the art of philosophizing in the sense of a mode of philosophizing (as it was previously suggested), then this mode has to be a phronetic mode - a phronetic mode of being in a dialogue. The decisive question now is, are philosophical practitioners always in this phronetic mode when being in a dialogue? Are they always mindful (as described above), when facilitating dialogues? An important remark in this respect seems to be Aristotle's notion that phronesis is a question of experience and "experience is the fruit of years" ${ }^{37}$. Related to a phronetic art of philosophizing (to call it like that), this would mean that the phronetic capacity of a philosophical practitioner would develop due to his or her experience, and over time. But is this true? Can younger or more inexperienced practitioners not adopt a phronetic attitude in their dialogues? And, as a consequence, would that mean that the dialogues they facilitate are rather 'poor' and 'weak' and of less quality? No, by far not. Experience is an advantage, for sure, but what seems to be of even greater importance is the intention of whether one is willing to be mindful in the dialogue facilitation. For example, one of the key features of the figure of Socrates in this respect, was his knowing of not knowing - this awareness of his unawareness which did not keep him from being curious, wondering, critical and interested in the topics under investigation. On the contrary, it even seems that this awareness of his unawareness was the reason why he could keep on having such a mindful attitude. In other words, Socrates knew his limitations, but in the writings of Plato it appears that this was not a problem for him. It does not seem that he was lacking confidence. And this awareness of his unawareness seem to have sparked his

${ }^{37}$ ARISTOTLE: Nicomachean Ethics, 1142a 6-7. 
philosophical investigations and the way he performed dialogues. And here we come back to the actual art of philosophizing, which seems to be deeply rooted in the wisdom of ignorance. Only due to this wisdom of ignorance, Socrates could keep on being curious, wondering, critical, but also authentic and humble. It kept him investigating, questioning and reflecting. In other words, an authentic concern for the topic - for the issue at stake - as well as for dialogue participants appears to be decisive in order to perform and facilitate good dialogues ${ }^{38}$. Of course, as the facilitator of a philosophical group dialogue - performed for example by means of the Socratic method after Nelson ${ }^{39}$ - one's role is not to engage in the dialogue like other group participants, in terms of sharing personal stories, ideas or opinions. Nevertheless, an authentic concern and interest for the topic is still of high relevance for the dialogue facilitator too, since it makes it easier for him or her to 'keep an ear to the ground'. That is, to listen carefully to what is expressed in the course of a dialogue, to sense important aspects, which can be further investigated, to pose helpful questions and of course to take care of the dialogue process as a whole etc. If a young or rather inexperienced philosophical practitioner has this authentic concern for the topic and the participants of a dialogue, and if he or she is aware of his or her not-knowing position, then these are important preconditions for that practitioner to perform the art of philosophizing (as presented here) too. On the other hand, if an experienced philosophical practitioner lacks an authentic concern for the topic under investigation, as well as for his or her 'co-investigators' and is rather 'bored' with one of the two, or with both, then it might be hard to sense this phronetic mode of being in a dialogue with him or her. The lack of concern and interest can be

${ }^{38}$ see GALLAGHER, Shaun: Hermeneutics and Education, Suny Press, Albany, NY, 1992, p. 198.

39 see WEISS, Michael Noah: The Socratic Handbook. Dialogue Methods for Philosophical Practice, LIT Publishing, Vienna, 2015, p. 215. 
a result of routine. Philosophical investigations, like Socratic dialogues, Philo Cafés, Philosophical Counseling etc. might be performed and facilitated by a philosophical practitioner on a daily basis in order to earn a living. Philosophical topics or questions like 'What is freedom?', 'Has life meaning?', 'How to live life in a responsible way?' etc. might be - though by different people investigated in a practitioner's praxis regularly. If a practitioner then looses his or her interest in the actual philosophizing process and instead solely resorts to applying certain techniques, methods and standardized procedures, then the activity performed by this practitioner rather resembles some sort of technè than praxis philosophical practice, in this case. Of course, no practitioner is immune from falling prey to such a situation caused by everyday work routines. But why such a situation is far from the art of philosophizing appears to be obvious. Another trap in this respect can be a philosophical practitioner's own experience. Though Aristotle assumed that phronesis is a question of experience and that "experience is the fruit of years" 40 , it can be precisely because of these years of experience, which a practitioner might have with philosophical investigations that he or she becomes overconfident and forgets about his or her knowing of not-knowing. And that, again, would counter the art of philosophizing, since such a selfconfident attitude with a practitioner would rather resemble the attitude one finds with some of Socrates' interlocutors, who were convinced they were wise - whereas in fact they were not.

\section{Poiesis vs. praxis}

With these remarks on the art of philosophizing in terms of a phronetic mode of being in a dialogue, I intended to approach the essence of philosophical practice. And this essence seems to have

${ }^{40}$ ARISTOTLE: Nicomachean Ethics, 1142a 6-7. 
something to do with the facilitation and the performance of dialogues - not only because more or less all philosophical practitioners are concerned with dialogue facilitation when doing philosophical practice, but also because the facilitation of dialogues seem to be a central feature when comparing philosophical practice with other approaches like psychotherapy or coaching ${ }^{41}$. To make this point more clear, a distinction from Aristotle seems to be useful. He differed between two kinds of concepts of action: The first he called poiesis and the other praxis ${ }^{42}$. Poiesis is the activity that is performed, when the goal of this activity is beyond the activity itself. An example here would be to build a house - the building process is not the goal but it is the finishing of the house. Praxis on the other hand is an activity done for its own sake. An example here would be to go for a walk, to relax, to listen to music - or to philosophize ${ }^{43}$. As a consequence, if the activity of philosophizing is assigned to praxis and if philosophical practice is assumed to be concerned with philosophizing then a philosophical practitioner's main concern is - or should be - the facilitation of philosophical investigations and dialogues (because what else could it be then?) At first sight this might appear to be problematic, since it makes it rather impossible to assign philosophical practice to the field of counseling professions: Though the field of counseling (including life counseling, business coaching etc.) is quite diverse by today, its general intention - as its name suggest is to give counsel. And with that the activity of counseling has its goal beyond itself and resembles a poietic activiy. On the other

\footnotetext{
${ }^{41}$ see SVARE, Helge: "Behandling eller dialog", in Impuls - tidsskrift for psykologi, Nr. 2, 2004, p. $59-65$.

42 see STAUDE, Detlef: "The Path of Consideration. Philosophical Practice in Dialogic Life Accompaniment", in WEISS, Michael Noah: The Socratic Handbook. Dialogue Methods for Philosophical Practice, LIT Publishing, Vienna, 2015, p. 43.

${ }^{43}$ see ibidem.
} 
hand, it is precisely this point that makes it possible to differ philosophical practice from psychotherapy, coaching and counseling: While psychotherapy is rather about healing and curing scars of the heart, and coaching is about improving or resolving a problematic situation, for example (which means that both approaches have their goals beyond the actual activities of treating or coaching, and with that rather resemble poiesis), philosophical practice has its goal within itself, that is, the goal of philosophizing is to philosophize, to investigate the mind. And with that philosophical practice rather resembles praxis $^{44}$. Whether philosophical practice indeed has its goal within itself, is heavily debated $^{45}$. For example, what if a guest visits a philosophical practitioner because she currently suffers from a lack of meaning in her life? Cannot a philosophical practitioner help her? The point is that this question is simply the wrong one. If philosophical practice is about solving existential problems, then it has to be assigned to poiesis and not to praxis. As a consequence, philosophical practice, strictly speaking, would not deserve to be called a practice then. Of course, it would answer several questions at once, if philosophical practice would indeed be about problem-solving and the like: First, it would be much easier to market it towards potential customers because they would know in advance what kind of 'product' or benefit they can expect (i.e. answers to urging existential questions, or improved performances in business companies). Second, and with regards to the assumption that all philosophical practitioners want to perform good dialogues (as described in the very beginning of this essay), it would also be much easier to conclude what it takes in order to have a good dialogue - it would be its results, for example, that a solution to the problem under investigation can

\footnotetext{
${ }^{44}$ see ibidem.

45 see RAABE, Peter: Philosophical Counseling. Theory and Practice, Praeger Publishers, Santa Barbara, CA, 2001, p. 120f.
} 
been found. Good dialogues could then be differed from 'weak' or 'poor' dialogues in terms of their outcomes. And good philosophical practitioners would then be those who can 'deliver' a needed solution for a problem in a simple, fast and comprehensible way. But, in order to stay true to what philosophical practice claims to be, namely to be a practice, we have to refrain from these tempting interpretations in terms of poiesis. However, if one agrees with this distinction between poiesis and praxis, and that the assignment of philosophical practice should fall into the realm of the latter, then the question is more than legitimate to ask why one should visit a philosophical practitioner, if one cannot expect any concrete outcome from such a visitation (since philosophical practice is not a poietic activity). In this respect the philosophical practitioner Detlef Staude states that he is

pleading to take Aristotle seriously, as he points at a deep difficulty in today's society, where we find it hard to get to rest, because we are constantly trying to reach aims. Perhaps the true power of philosophy lies in its being centered in itself. This could be the power so many people nowadays are looking for. Philosophical practice is a dialogue, which brings nearer to freedom and closer to oneself. It is not a tool for success nor is it a tool for anything else. To be human does not just mean to be a homo faber, to be someone who only pursues purposes and uses the power of thinking for reaching these purposes. Purposes are always ambivalent, have different aspects and implications. So one shouldn't say that philosophical practice is 'the application of philosophy', because saying so suggests that philosophy is a tool for a purpose, but the purpose itself has nothing to do with philosophy. However, philosophizing is deeply human, it is not the poiesis of something, but the praxis of a free human being. And as it is this free praxis, to exercise it can bring us to become even more free ${ }^{46}$

${ }^{46}$ STAUDE, Detlef: "The Path of Consideration. Philosophical Practice in Dialogic Life Accompaniment", in WEISS, Michael Noah: The Socratic Handbook. Dialogue Methods for Philosophical Practice, LIT Publishing, Vienna, 2015, p. 43. 


\section{Learning self-knowledge}

If philosophical practice is not a poietic activity, as i.e. psychotherapy or coaching in fact are, but rather a dialogical praxis then the question is, what are the competences of a philosophical practitioner in this respect - if he or she has any competences at all? This question seems to be legitimate, since philosophical practice in one way or another understands itself as a profession (for example, when comparing itself with psychotherapy or coaching, as documented in the respective literature ${ }^{47}$ ). And in order to pursue a certain profession, one has to have respective competences. One could now come to the conclusion that philosophical practitioners are some sort of dialogue experts and that they have the formal competence to facilitate dialogues on a professional level. This understanding would keep philosophical practice still within the scope of praxis and not 'delivering' it to poiesis. At the same time however, one can ask what this dialogical competence is about, if it is not a matter of techniques, methods and tools - in short, a matter of know-how or techné. And here we return to what has been discussed previously under The Art of Improvisation. There, art has rather been defined in the sense of a mode of being than in the sense of craftsmanship. And if we now take this understanding of art as well as Aristotle's distinction between poiesis and praxis (and with that the distinction between techné and phronesis) into account, then we can conclude that the dialogical competences of a philosophical practitioner are not so much concerned with know-how and technical knowledge nor with problem-solving skills, but rather with an attitude - a phronetic attitude. In other words, the art of philosophizing is not simply a matter of dialogue techniques and communication skills - and that

47 RAABE, Peter: Philosophical Counseling. Theory and Practice, Praeger Publishers, Santa Barbara, CA, 2001, p. 79. 
by learning these skills and techniques it would make one into a good philosophical practitioner. Rather, learning phronesis (or mindfulness, as it was translated previously) is a matter of selfknowledge, as Shaun Gallagher points out, when investigating the passage in the Plato's dialogue Meno, where Socrates and Meno reflect on how one can learn phronesis, if it is not teachable. In this respect, Gallagher states that,

Self-knowledge, which is intimately linked with phronesis and thinking for oneself, is clearly contrasted, not only to Meno's reliance on memorized definitions, but to the type of knowledge offered by the Sophists. Even those Sophists, like Gorgias, who, through clever technique, could compose fine-sounding and memorable definitions do not represent for Plato the ideal of education. Education is more than rhetorical technique, as characterized by Plato. Rhetoric, as practiced by Sophists such as Gorgias, is a collection of purely formal techniques used to impress those who listen. As a formal technique is does not manifest moral involvement and concern for student, subject matter, or truth. If we define art (a term that in English once signified "learning") as a practice that manifests such moral concern, then for Plato education has more to do with art than with formal, unconcerned techné. The notion that art or learning involves moral concern would not be irrelevant to the concept of virtue (areté) or phronesis under discussion in the Meno ${ }^{48}$

These remarks of Gallagher offer valuable clues on what has been called the phronetic mode of being in a dialogue in this essay. First, Gallagher clearly dismisses the teaching of rhetorical techniques or communication skills (which he here attributes to the Sophists) as being sufficient for the learning of phronesis. Learning phronesis is a different type of education, so to say. It has to do with gaining self-knowledge, and only through self-knowledge a true moral involvement and concern "for student, subject matter, or truth"

48 GALLAGHER, Shaun: Hermeneutics and Education, Suny Press, Albany, NY, 1992, p. $198 f$.

49 ibidem. 
possible. In other words and seen from Gallagher's point of view, the phronetic attitude required by a philosophical practitioner in the facilitation of dialogues fundamentally relies on his or her will to gain self-knowledge. If it would only be about acquiring formal techniques then this would "not manifest moral involvement and concern" $"$. The second important remark that Gallagher makes here can be found at the end of his quote, where he states that, "If we define art (a term that in English once signified 'learning') as a practice that manifests such moral concern, then for Plato education has more to do with art than with formal, unconcerned techné." With this statement, Gallagher clearly relates art to phronesis, however - and even more importantly it seems - he also links up art with learning. If we go along with Gallagher, then the art of philosophizing in the sense of a phronetic mode of being in a dialogue is about learning in and from the dialogue about oneself (that is, gaining self-knowledge). However this 'learning about oneself' is not meant in a self-centered, egoistic or even solipsistic way. On the contrary, it is centrally concerned with the question 'How do I relate to the dialogue participants and the topic under investigation - and what can I learn in that respect from the given situation'? This is what Gallagher means with moral concern and involvement, which according to him is not "irrelevant to the concept of virtue (areté) or phronesis." ${ }^{, 52}$ If we now assume that art involves moral concern and involvement, and that it is related to phronesis, then we have to conclude that the art of philosophizing lays essentially in the learning of being sensitive and mindful when performing and facilitating dialogues. As a consequence, a philosophical practitioner would then never be, or become, an expert in the sense of someone who has certain competences that he or she could teach away. Rather, a philosophical practitioner

\footnotetext{
50 ibidem.

51 ibidem.

52 ibidem.
} 
would always remain a novice, a layman on the subject, which is precisely what the wisdom of ignorance tells us. But that does not mean that he or she does not have an eager, curious, wondering, brave and adventurous mind, that is, a true and authentic interest for the subject matter and for what other dialogue participants can contribute with, when investigating this subject. And with that we can summarize what has been said so far about the question guiding this essay, namely: 'What skills or qualities with the philosophical practitioner are required in order to perform and facilitate a good dialogue?'

\section{Concluding and summarizing remarks}

The basic assumption on which the reflections of this essay are based is that one common feature among all philosophical practitioners is that they intend to create, perform and facilitate dialogues. In the further course of this essay it was then assumed that philosophical practitioners do not only intend to facilitate and perform dialogues but that they want to facilitate and perform good dialogues. Therefore, the guiding question of this essay was 'What skills or qualities with the philosophical practitioner are required in order to perform and facilitate a good dialogue?'

In order to go into this question it first had to be clarified what is meant with a good dialogue. For that purpose, an analogy to the good life as introduces by Aristotle was made, where it was pointed out that just like the good life a good dialogue is more of a normative idea and rather empty of content.

However, in order to assume a good dialogue as a normative idea it then had to be clarified what a dialogue as such actually is. In that respect the Community of Inquiry concept from Matthew Lipman was introduced ${ }^{53}$. According to this concept a dialogue

${ }^{53}$ see LIPMAN, Matthew: Thinking in Education, Cambridge University Press, 
means to investigate a topic or a phenomenon together, in order to get a deeper or broader understanding of it.

In the course of this essay, a good dialogue was then compared with a good jazz performance. Such a performance is not only a question of playing skills and techniques mastered by the respective musicians. Rather, a good jazz performance is essentially characterized by the improvised interaction between the musicians - it is the art of improvisation that makes a jazz performance a good one.

The art of improvisation was then further examined and it was pointed out that this art is not so much a question of playing skills. Rather, it has been concluded that the art of improvisation has more to do with a mode - and musicians are in a certain mode of improvisation, when giving a good jazz performance.

Understanding art in the sense of a mode of being is quite different from what Aristotle understood by the term. Nevertheless, with regards to the etymological roots of the term art it appeared to be legitimate to interpret art in the sense of a mode. In a next step it was then asked what the art of philosophizing, when understanding it as some kind of mode of philosophizing, would be about.

For that purpose a closer look on the term philosophizing was taken and a rather literal translation of philosophy in the sense of philo-sophia (the love of wisdom) was taken into account. With regards to the term wisdom, it was pointed out that Aristotle differed between two kinds of wisdom: theoretical wisdom (sophia) and practical wisdom (phronesis). While theoretical wisdom was assumed - in general terms - to be concerned with an understanding of the cosmos and the human being in the world, practical wisdom was assumed to be concerned with an understanding about what ought to be done in a given situation in regards to live a good and virtues life overall.

Cambridge, 2003, p. 84. 
Based on this differentiation between sophia and phronesis it has been concluded that a philosophical dialogue can, but does not necessarily have to be about topics related to sophia. Phronesis, on the other hand, always does - or at least should - play a role in a dialogue, at least to a certain extent. In order to point out the intrinsic role of phronesis in a dialogue, a closer look at the ethical dimension inherent in a dialogue has been taken. Here it was concluded that if a dialogue in its essence is some sort of an investigative cooperation - a communicative interaction by which something is investigated together - then this form of interaction would cease if its ethical dimension would be violated, i.e. when a dialogue turns into a debate or a discussion.

In the further course of this essay, it was then asked for the relevance of phronesis in regards to this ethical dimension of a dialogue. In order to find answers, the dialogues of Socrates, as presented in the writings of Plato, were reflected. In these reflections it appeared that it was the attitude of Socrates, which he employed in these dialogues that essentially contributed to their course and their outcome. With reference to the wisdom of ignorance ('I know that I know nothing') it was concluded that the attitude of Socrates in his dialogues was a phronetic one.

Based on these reflections, the art of philosophizing could be understood in the sense of a phronetic mode of being (in a dialogue). In order to further investigate this phronetic mode of being, a specific translation of phronesis was introduced, namely: phronesis as mindfulness (as suggested by McEvilley ${ }^{54}$ ). In this respect two central dimensions of mindfulness have been identified: a reflective dimension (i.e. to think critically, to reflect on one's thoughts and intuitions, to examine one's ideas) and a caring dimension (i.e. to care about what others say in a dialogue,

${ }^{54}$ see McEVILLEY, Thomas: The Shape of Ancient Thought, Allworth Press, New York, NY, 2002, p. 609. 
to care for the topic under investigation) - and both dimensions appeared to be essential for the art of philosophizing in the sense of a phronetic mode of being in a dialogue. One of the conclusions then was that a philosophical practitioner, when intending to perform and facilitate a good dialogue, has to be mindful.

The question then was whether facilitating good dialogues essentially relies on this mindful attitude with the practitioner, or whether certain communication skills and techniques would also be required and necessary. In this respect Aristotle's differentiation between poiesis and praxis was introduced: poiesis as an activity, which has its goal beyond this activity (i.e. building a house), and praxis as an activity, which has its goal within itself. If one goes along with this differentiation between poiesis and phronesis then i.e. psychotherapy can be attributed to the activity of poiesis: The goal of psychotherapy i.e. is healing and curing - and both healing and curing lay beyond the activity of therapeutic conversations. Philosophizing on the other hand has no goal beyond itself - its goal is not to solve a problem or to improve a given situation. Of course, solving a problem or improving a situation can be the outcome of philosophizing, but this rather has to be regarded as a side effect. Philosophizing - in a metaphorical sense - is like doing a walk into our mindscape, comparable to a walk in the woods after coming home from work. A walk into the woods will not solve the challenges we have at work, rather we do the walk because we enjoy being in nature, or for whatever other inherent reason. Of course, however, it can be that on such a walk an idea about how we can solve a certain problem at work comes to our mind spontaneously. But the activity of walking as such cannot guarantee that we in fact will find such a solution - that happens incidentally.

With attributing the activity of philosophizing, and with that philosophical practice, to praxis, a delicate question comes to the fore: What kind of competences does - or at least should - a philosophical practitioner have, if he or she does obviously not 
have competences in order reach certain goals or 'produce' certain outcomes with his or her work?

With this question the course of this essay returned to what has been called a phronetic mode of being as a certain quality of mind, so to speak. If we understand art with regards to its etymological roots in the sense of mode, then the art of philosophizing is a phronetic mode of being in a dialogue, that is, in simple words being mindful. In other words, the essence of a good dialogue is not about certain techniques or methods. Rather it is about a mindful attitude with which a philosophical practitioner is doing and facilitating a dialogue. As a conclusion, good dialogues essentially depend on the facilitator and the participants being mindful (in the sense of being phronetic).

The question was also raised what it could be that 'triggers' a philosophical practitioner in order to develop mindfulness (that is, phronesis). In connection with this question a quote from Shaun Gallagher's "Hermeneutics and Eduation" was presented, in which he introduces three key-terms regarding phronesis: self-knowledge, art and learning ${ }^{55}$. Interestingly, Gallagher equals art with learning - learning in the sense as Plato actually meant it, namely as learning moral knowledge (which here is a translation of phronesis). And moral knowledge here can be interpreted as moral involvement and concern for the other dialogue partners, the subject matter and truth ${ }^{56}$. On the other hand, Gallagher also pointed out that learning phronesis is intimately connected with gaining self-knowledge. Hence, for the purpose of this essay, it can be concluded that the art of philosophizing as a phronetic mode of being in a dialogue is about learning in and from the dialogue about oneself (which is, gaining self-knowledge). And this 'learning about oneself' is centrally concerned with the question

55 GALLAGHER, Shaun: Hermeneutics and Education, Suny Press, Albany, NY, 1992, p. 198f.

56 see ibidem. 
'How do I relate to the dialogue participants and the topic under investigation - and what can I learn in that respect from the given situation?' And finally it appears to be the essence of this very question, which seems to be decisive for all philosophical practitioners in order to have and facilitate good dialogues - or not.

\section{References}

AMIR, Lydia: "The Tragic Sense of the Good Life", in WEISS, Michael Noah (ed.): The Socratic Handbook. Dialogue Methods for Philosophical Practice, LIT Publishing, Vienna, 2015.

DICT.CC: "thou art" available in HUhttps://www.dict.cc/?s=thou+artUH (last access July $11^{\text {th }}$ 2016) FRANKL, Viktor E.: Man's search for ultimate meaning, Perseus Publishing, Cambridge, MA, 2000.

GALLAGHER, Shaun: Hermeneutics and Education, Suny Press, Albany, NY, 1992.

HARRINGTON A. \& DUNNE, J. D.: "When mindfulness is therapy: Ethical qualms, historical perspectives", in American Psychologist, Nr. 7, Vol. 70, 2015.

LAHAV, Ran \& DA VENZA TILLMANNS, Maria (eds.): Essays on Philosophical Counseling, Plymbridge Distributors Ltd., Gloucester, 1995.

LINDSETH, Anders: "Being Ill as an Inevitable Life Topic. Possibilities of Philosophical

LIPMAN, Matthew: Thinking in Education, Cambridge University Press, Cambridge, 2003.

McEVILLEY, Thomas: The Shape of Ancient Thought, Allworth Press, New York, NY, 2002.

NIEHAUS, Michael: "Philosophy as a Way of Life. Exercises in Self-Care", in WEISS, Michael Noah (ed.): The Socratic Handbook. Dialogue Methods for Philosophical Practice, LIT Publishing, Vienna, 2015. 
ONLINE ETYMOLOGY DICTIONARY: "art" available in HUhttp://www.etymonline.com/index.php?term=artUH (last access July $11^{\text {th }} 2016$ )

Practice in Health Care and Psychotherapy", in WEISS, Michael Noah (ed.): The Socratic Handbook. Dialogue Methods for Philosophical Practice, LIT Publishing, Vienna, 2015.

RAABE, Peter: Philosophical Counseling. Theory and Practice, Praeger Publishers, Santa Barbara, CA, 2001.

SEESKIN, Kenneth: Dialogue and Discovery. A Study in Socratic Method, State University of New York Press, New York, 1987.

SHIELDS, Patricia M.: "The Community of Inquiry: Classical Pragmatism and Public Administration", in Administration \& Society, Nr. 5, Vol. 35. 2003.

STAUDE, Detlef, "The Path of Consideration. Philosophical Practice in Dialogic Life Accompaniment", in WEISS, Michael Noah, The Socratic Handbook. Dialogue Methods for Philosophical Practice, LIT Publishing, Vienna, 2015.

SVARE, Helge, "Behandling eller dialog", in Impuls - tidsskrift for psykologi, Nr. 2, 2004, p. 59-65.

TARRANT, Dorothy: "Style and Thought in Plato Dialogues", in Classical Quarterly, Nr. 42, 1948, Pags. 28-34.

TEICHMANN, Jenny \& EVANS, Kathrine C., Philosophy - A Beginner's Guide, Blackwell, Oxford, 1999.

WEISS, Michael N. (ed.): The Socratic Handbook. Dialogue Methods for Philosophical Practice, LIT Publishing, Vienna, 2015. WEISS, Michael Noah, The Socratic Handbook. Dialogue Methods for Philosophical Practice, LIT Publishing, Vienna, 2015.

WEISS, Michael Noah: "Ethical Guidelines for Philosophical Dialoguing? From Global Ethic Towards a Professional Ethics for Philosophical Practice", in Journal of the American Philosophical Practice Association, Nr. 3, Vol. 10, 2015. 
